九州大学学術情報リポジトリ

Kyushu University Institutional Repository

\title{
Growth, Canopy Structure and Seed Yield of Mungbean as influenced by Water Stress
}

Is lam, Muhammad Tajul

Laboratory of Practical Botany, Faculty of Agriculture, Kyushu University

Kubota, Fumitake

Laboratory of Practical Botany, Faculty of Agriculture, Kyushu University

Agata, Waichi

Laboratory of Practical Botany, Faculty of Agriculture, Kyushu University

https://doi.org/10.5109/24053

出版情報：九州大学大学院農学研究院紀要. 38 (3/4)，pp.213-224，1994-03. Kyushu University バージョン：

権利関係 : 


\title{
Growth, Canopy Structure and Seed Yield of Mungbean as influenced by Water Stress
}

\author{
Muhammad Tajul Islam, Fumitake Kubota and Waichi Agata
}

Laboratory of Practical Botany, Faculty of Agriculture, Kyushu University 46-01, Fukuoka 812, Japan

(Received December 27, 1993)

\begin{abstract}
Growth, canopy and seed yield of mungbean were evaluated under water stress conditions at the Kyushu University Experimental Farm during the summer of 1992. Waterlogging, optimum moisture (control) and drought conditions constituted the treatments. The treatments were initiated before the onset of flowering. The results indicated that both the water stress (waterlogging and drought stress) treatments had significant adverse affect on the morpho-physiological characters of mungbean. Plants under waterlogging conditions were affected more in most of the characters studied. Lower leaf area production, low CGR and low NAR contributed to the low TDW of the waterlogged plants compared to the other two treatments. At final harvest, the difference between the two stress treatments was about $10 \%$. The distribution pattern of the dry matter was more or less similar in all the treatments except for roots. Among the treatments, drought stressed roots had the highest dry matter and the waterlogged roots had the lowest. The roots of the waterlogged plants became fibrous. There were distinct variations in the canopy structures under different treatment conditions. Most of the foliage for plants under control and waterlogged conditions were distributed in between upper and middle strata of the canopy, while for drought stress it was from middle to lower strata. There was increase in stem dry weight with decrease in height from the top regardless of the treatments. The maximum value for light extinction coefficient $(0.82)$ was in the waterlogged plants.

Significantly high seed yield (7.06 g per plant) was obtained in control treatment followed by drought stress $(4.21 \mathrm{~g})$ and waterlogging $(2.30 \mathrm{~g})$. Seeds per plant and pods per plant contributed more to the seed yield per plant than the other yield contributing components. It is evident from this study that mungbean growth, canopy and seed yield are more susceptible to waterlogging than drought stress.
\end{abstract}

\section{INTRODUCTION}

Water stress includes both drought and waterlogging. Both the factors have severe adverse effect on the productivity of the crop. The effect of drought stress on the performance of crop growth, development and productivity has been studied and reported extensively. Hisao (1973), Schulze(1986), Jones and Corlet (1992) discussed in detail about the impact of drought on the morpho-physiological aspects and productivity of crops. Drought restricts the canopy development and reduces crop growth rate (Phogat et al., 1984 a, 1984 b; Muchow, 1985; Sinclair et al., 1985). Water deficit also influences the partitioning of dry matter from vegetative parts to grain. The productivity of many diverse crops can be closely related to light interception (Monteith 1977), and the critical effect of drought on canopy light interception, leaf area duration and yield has been well documented (Legg et al., 1979). In addition to this major cause of reduced productivity, there is considerable evidence that drought changes the efficiency of conversion of intercepted light into dry matter. 
Waterlogging is also unique among the plant stresses because of prompt and lasting effects on carbon budget to root and shoot (Trought and Drew, 1980). Growth, canopy production and productivity of crop are severely affected by waterlogging. The thorough growth analysis study by Trought and Drew (1980) also revealed the severity of the stress on the productivity. The root metabolism of most of the crop plants (which lack specialized gas conducting structures and special anaerobic metabolic pathways found in wetland species) is immediately restricted when oxygen in the root zone falls below a critical level (Armstrong and Gaynard, 1976), shoot assimilation and metabolism respond to waterlogging more slowly (Wiedenroth and Poskuta, 1978).

Mungbean in the tropical and sub-tropical regions can be grown three times a year. Since it is cultivated as a rainfed crop, depending on the sowing time, it very often experiences both short and long rainless and rainy days during its growth cycle. This results either in drought or waterlogging conditions. The crop is also subjected to water stress due to receding soil moisture and rising temperature. There are several reports on the influence of drought stress on mungbean, but very few are available on the impact of waterlogging on mungbean. However, no report is available on the evaluation of the morpho -physiological characters and productivity of mungbean as influenced by both the stresses for the crop grown under the adequate environmental condition. Thus present study was undertaken to make a comparative analysis of drought and waterlogging stresses on mungbean canopy and seed yield.

\section{METHOD AND MATERIAL}

Mungbean seeds (variety Mobarik) were sown in the water controllable plots at the Kyushu University Experimental Farm on the 18th May 1992. The experimental area was covered with white transparent polyethylene sheets to prevent rain water. The experimental plots were constructed by concrete walls around each plot to simulate the soil moisture gradients. Each plot was filled with sandy loam soil which had low water holding capacity. The differences in soil moisture levels were made by the height of water level in the interconnected water reservoirs adjacent to each plot. Compound chemical fertilizer $\left(\mathrm{N}: \mathrm{P}_{2} \mathrm{O}_{5}: \mathrm{K}_{2} \mathrm{O}=16: 16: 16\right)$ of $20 \mathrm{gm}^{-2}$ were well mixed with the soil before seeding. Two pre-germinated seeds per hole were sown at a distance of $10 \mathrm{~cm} \times 30 \mathrm{~cm}$ for plant to plant Xrow to row distance, respectively. Seedlings emerged five days after seeding. At two-leaf stage, the seedlings were thinned to one per hole.

There were three treatments in this study, 1) waterlogging 2) optimum soil moisture (control) and 3) drought. The treatments were imposed at the pre-flowering stage (26 days after emergence of the seeds). Sampling for growth analysis was done at every 7 days interval starting from the day of treatment initiation. Five plants were sampled for each treatment in each sampling. The sampled plants were segmented into leaf, stem (including petiole), root and reproductive structures. The leaf area was measured by an automatic area meter (Model AAM 8, Hayashi Denko, Japan). The segmented plant parts were oven dried at $80^{\circ} \mathrm{C}$ for 48 hours. Finally the dry weight was measured by an electronic balance.

Measurements for canopy structure and light interception at different canopy levels were done on the 18th day after the treatments were imposed. A quadrate of $50 \mathrm{~cm} \times 50$ 
$\mathrm{cm}$ with $1 \mathrm{~m}$ height was used for the measurement. The measuring procedure was followed as stated by Goldsworthy (1970). As per the method, the canopy heights were divided at every $10 \mathrm{~cm}$ interval by marking the pegs of the quadrate by a marker pen, marking 0 at the ground level. Red colored thin string was placed at each height level diagonally and rectangularly attaching with the quadrate to define the canopy at that level. The plant components (leaf, stem, petiole and reproductive structures) were clipped and separated at each height level. Clipping was initiated from the top of the plant. Care was taken to avoid the destruction of the geometry of the foliage distribution. The area of the sampled green leaves and their dry weights were measured as described earlier. For light interception measurement, a solarimeter was used. The light sensor was penetrated into the canopy at every $10 \mathrm{~cm}$ interval at each height level.

At final harvest, plant height, leaf area, seed yield, number of pods per plant, seeds per pod, pod length, 100-seed weight were recorded from 10 plants of each treatment.

\section{RESULTS}

Growth analysis

The growth of mungbean was considerably affected by both waterlogging and drought conditions. The total dry weight (TDW) increased till final harvest of the crop in all the treatments. Plants under control treatment maintained a higher level of dry matter followed by drought and waterlogging treatments (Fig. $1-\mathrm{A}$ ). On the 7th day after treatments were imposed, the difference in TDW compared to control were $35 \%$ and $22 \%$ for waterlogging and drought plants, respectively. But after 15 days of stress imposition, the differences in TDW started widening between control and stress treatments. At final harvest the differences in TDW compared to the control plants were $51 \%$ and $40 \%$ for waterlogged and drought stressed plants, respectively.

The leaf area index (LAI) was also higher in plants in control treatment followed by drought and waterlogged plants (Fig. $1-B$ ). Till 15 days after treatments were imposed, the LAI values were close in all the water conditions. But since then, the plants in control plots had a sharp increase in LAI attaining a value of 4.39 on 21 days after treatments were imposed.

Figure 2-A and 2-B represent the time course of crop growth rate (CGR) and net assimilation rate (NAR) under different water levels, respectively. Both CGR and NAR were higher for plants in control plots. The trend of increase or decrease with treatment was similar to that of TDW. The NAR of 21 days after stress treatments were imposed appeared to be very close in all the treatments. The decrease in NAR in control treatment was more sharp than in the other two treatments.

The relationships between CGR and NAR with LAI (Fig. 3 -A and 3 - B) indicate that CGR increased and NAR decreased with the increase in LAI. At the same LAI, there were higher CGR and NAR for plants in control plots, this was followed by drought and waterlogged plants.

At final harvest, reproductive structures had the highest accumulated dry matter in all the treatments (Fig. 4). 


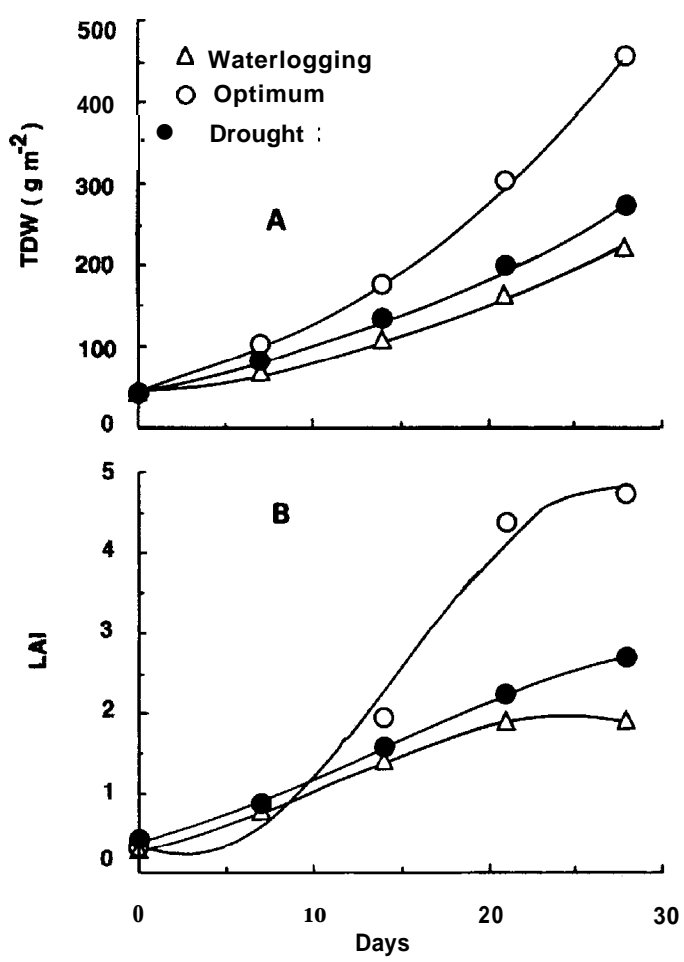

Fig. 1. Time course of total dry weight (A), and leaf area index (B) of mungbean under different water levels. (The symbols are the same for both the figures).

In plants grown under control treatment, $47 \%$ of the dry matter was found in reproductive structures. Leaves followed reproductive structures in terms of dry matter accumulation. At harvest, there seemed to be very little difference of treatment effect on dry matter accumulation in leaves. The distribution of dry matter to the stems were higher in control plants compared to the other plants. On the contrary, the partitioning of dry matter to the roots was higher in drought stressed plants compared to those of the other two treatments. The root shoot ratio in the drought stressed plants was the highest and the waterlogged plants was the lowest.

\section{Canopy structure}

Although the variation of LAI among the treatments was not large enough, the influence of water levels was clearly visible on the canopy structure (Fig. 5). The canopy height in the control plants was up to $70 \mathrm{~cm}$, while in the waterlogged and drought plants it was 50 and $60 \mathrm{~cm}$, respectively. Most of the leaves were distributed in the middle strata of control and waterlogged plants, while in drought plants it was from middle to lower strata of the plant. In the waterlogged plants, $40 \%$ of the total leaf mass was in upper $20-30 \mathrm{~cm}$ layer. In the control plants, $61 \%$ of the total foliage lied in the $30-50 \mathrm{~cm}$ layer and $49 \%$ of the leaves in drought stressed plants were distributed in the $20-40 \mathrm{~cm}$ layer.

The stem dry matter weight increased with decrease of height in all the treatments. 


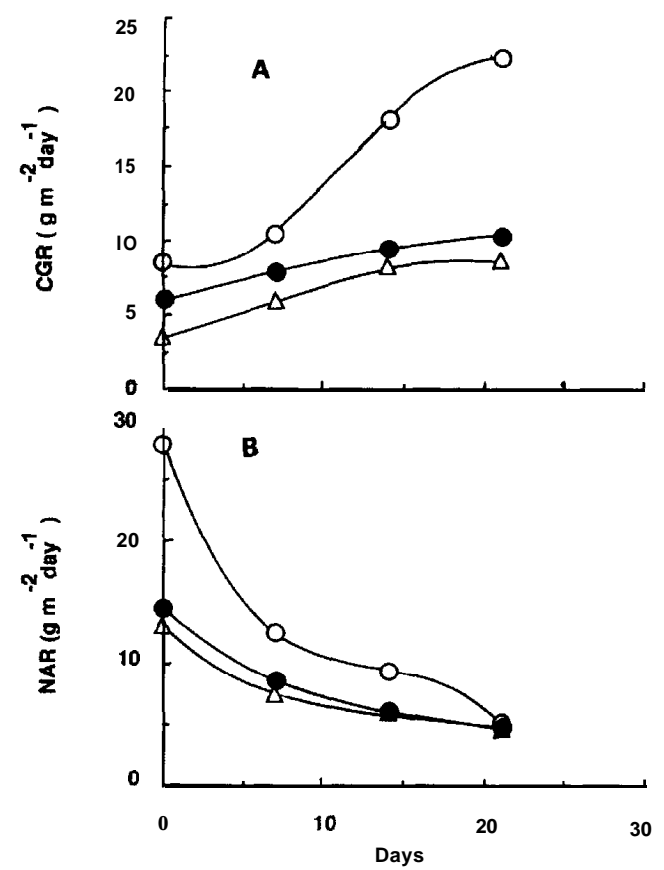

Fig. 2. Time course of crop growth rate (A), and net assimilation rate (B) of mungbean under different water levels. (The symbols are the same as in Fig. 1-A).

In control plants, a maximum stem dry weight of $25.48 \mathrm{~g} \mathrm{~m}^{-2}$ was found in the $\mathrm{O}-10 \mathrm{~cm}$ stratum. Depending upon the plant height, maximum amount of petiole lied in the middle strata of the plant except for water logged plants which had maximum amount of petiole distributed in the lower strata. Reproductive structures were distributed from the upper strata to the middle strata. There was no reproductive structure in the lower strata of the plant.

The amount of foliage, their distribution over the whole canopy and the leaf angle as affected by length and strength of the petiole, made differences in the interception pattern of the incident solar radiation. The light extinction coefficient $(\mathrm{K})$ analysis study revealed that $\mathrm{K}$ value differed between the treatments (Fig. 6). The maximum $\mathrm{K}$ value $(0.82)$ was in the waterlogged plants and the minimum (0.49) was in the control plants.

\section{Seed yield}

Water stress had significant effect on the seed yield and yield components of mungbean (Table 1). Significantly high seed yield was obtained in control plants (7.06 g plant- $\left.{ }^{-}\right)$. Waterlogged plants had the lowest yield $\left(2.30 \mathrm{~g} \mathrm{plant}^{-1}\right)$ which was $67 \%$ lower than that of the control plants and the reduction in the drought stressed plants was $40 \%$ compared to control plants. The reduction in seed yield of waterlogged plants was $45 \%$ of that of drought stressed plants. Number of seeds per plant, which is a product of seeds per pod and pods per plant, was significantly different between the 

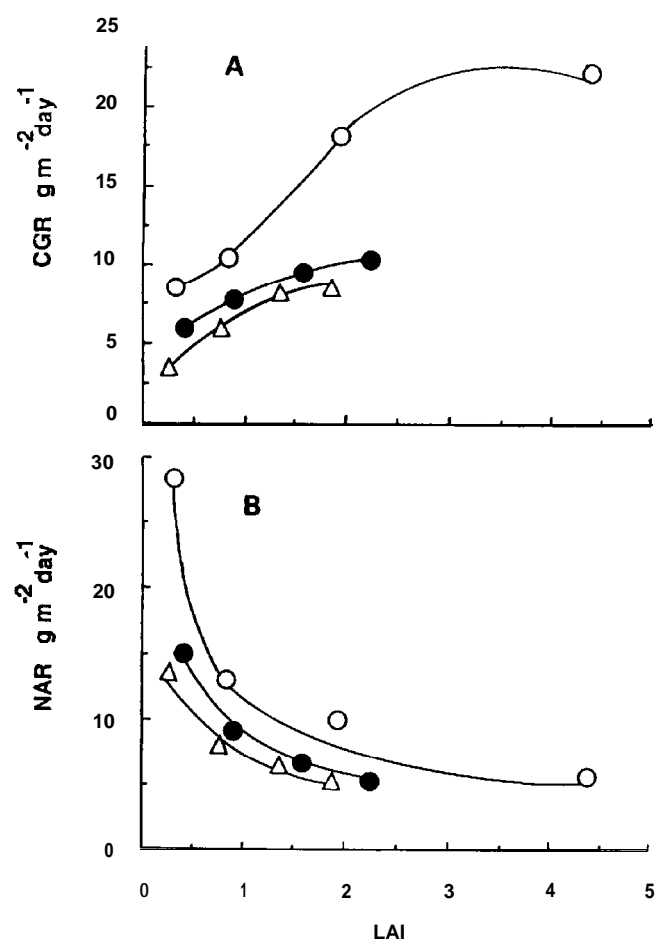

Fig. 3. Relationships between leaf area index with crop growth rate (A), and net assimilation rate $(\mathrm{B})$. (The symbols are the same as in Fig. 1-A).

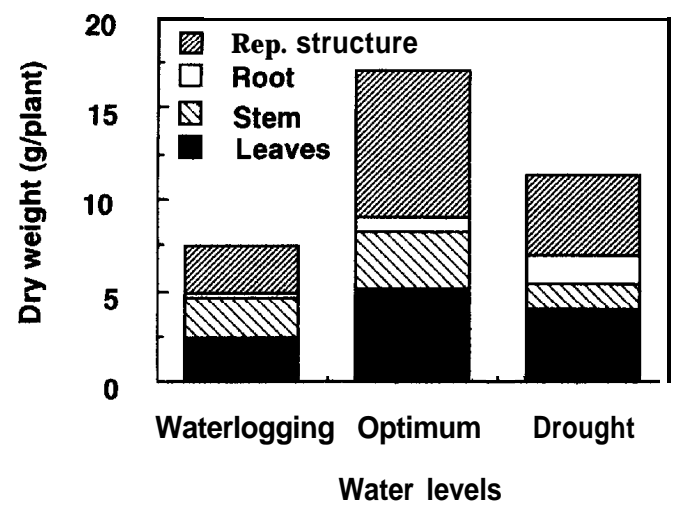

Fig. 4. Componentwise dry weight of mungbean at harvest under different water levels. 

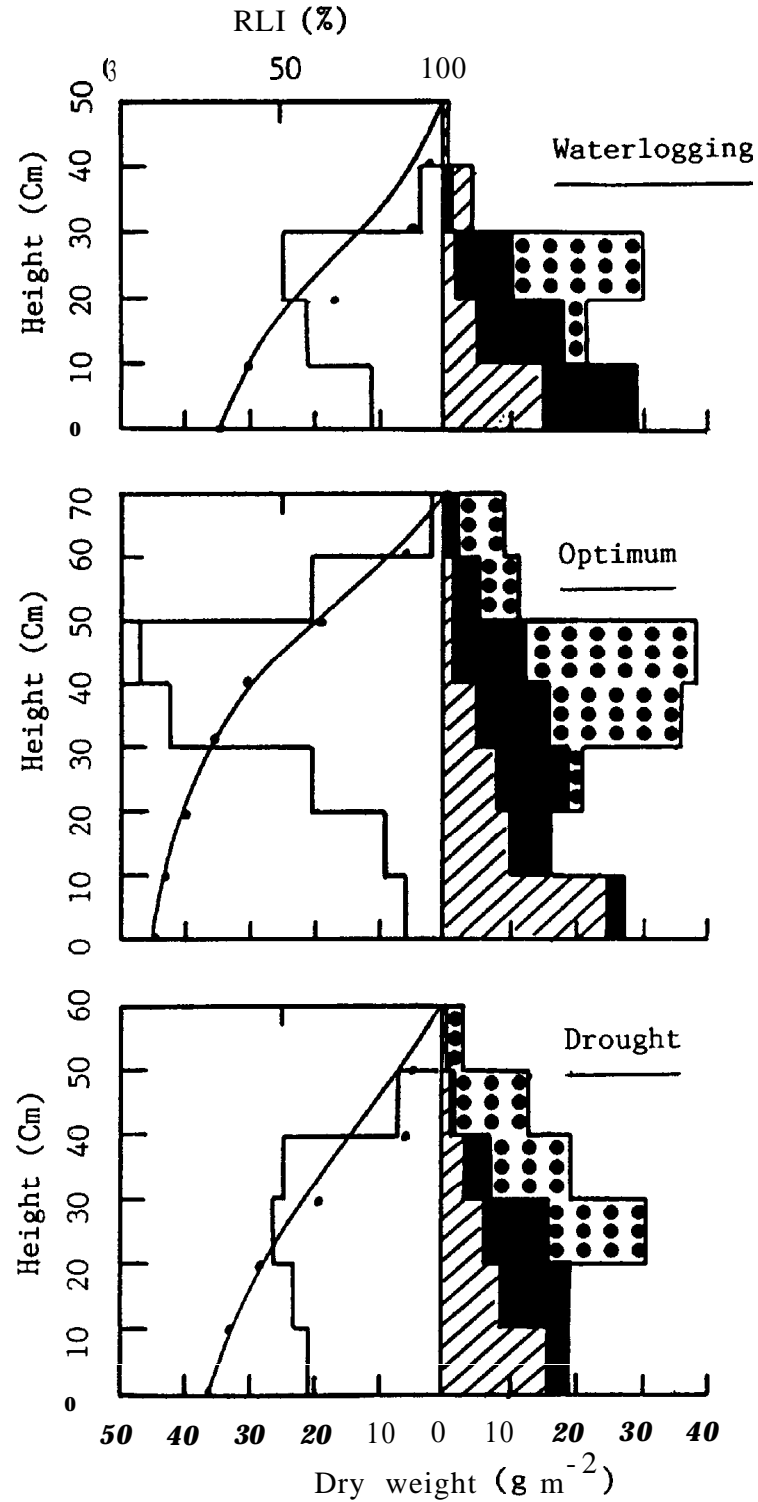

Fig. 5. Distribution of dry matter at different canopy levels under different water levels. ( $\square$ leaf, $\bigcirc$ stem, $\square$ petiole and reproductive organs). 


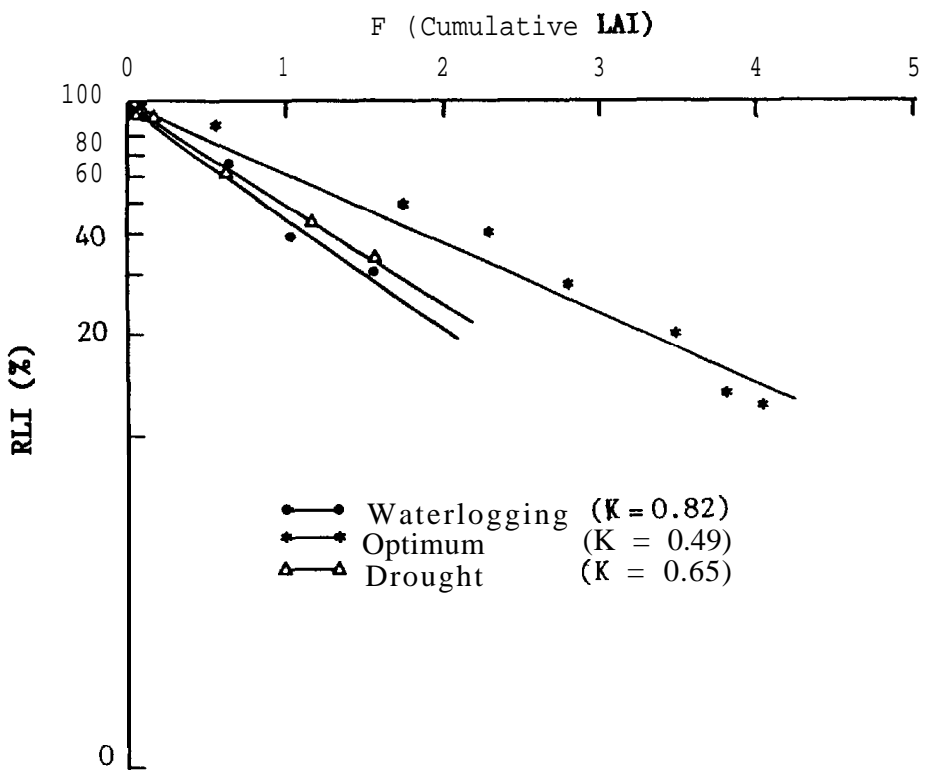

Fig. 6. Effect of different soil moisture levels on the relative light intensity in the crop canopies. (K represents the light extinction coefficient).

treatments. The result shows a similar trend as that of seed yield per plant. There was no significant difference between control and drought treatments for 100 -seed weight. Waterlogged plants had the lowest 100 -seed weight $(2.44 \mathrm{~g})$ among all the treatments. Seeds per pod also had similar results as that of 100 -seed weight. However, significant differences existed between the treatments when pods per plant was considered. Control plants had 24.10 pods per plant which was $136 \%$ and $47 \%$ more than those of the waterlogged and drought stressed plants, respectively. There was significant difference between control and drought stressed plants for pod length but no significant difference with waterlogged plants.

Table 1. Seed yield and yield components as affected by different moisture conditions.

\begin{tabular}{|c|c|c|c|c|c|c|}
\hline Treatment & $\begin{array}{l}\text { Seed yield } \\
\text { (g plant") }\end{array}$ & $\begin{array}{l}\text { Seeds plant- } \\
(\mathrm{g})\end{array}$ & $\begin{array}{c}\text { 100-seed weight } \\
\text { (no.) }\end{array}$ & $\begin{array}{l}\text { Seeds pod-' } \\
\text { (no.) }\end{array}$ & $\begin{array}{l}\text { Pods plant-' } \\
\text { (cm) }\end{array}$ & Pod length \\
\hline & & 100.8 & 2.4 & $9.82 "$ & 10.2 & $6.21^{\mathrm{at}}$ \\
\hline $\mathrm{Cor}$ & $7.06^{\mathrm{b}} \pm$ & $252.51^{b} \pm 2$ & $3.45^{\mathrm{b}} \pm 0.10$ & $10.43^{\mathrm{b}} \pm$ & $24.10^{\mathrm{b}} \pm 1.55$ & $6.47 "$ \\
\hline Drought & $4.21^{\prime} \pm 0.37$ & $146.30^{\prime} \pm 10.98$ & $3.29^{b} \pm 0.07$ & $8.84^{\mathrm{b}} \pm 0.21$ & $16.40^{\prime} \pm 0.91$ & $6.02^{\mathrm{b}} \pm 0$ \\
\hline
\end{tabular}

All values represent mean \pm standard error.

Values with the same letter in a column are not significantly different from each other at the 5\% level. 
Table 2a. Relationship between seeds yield and yield components as affected by waterlogged conditions.

\begin{tabular}{|c|c|c|c|c|c|}
\hline Seeds & plant-' & 100 -seed weight & Seeds pod-' & pods plant“" & Pod length \\
\hline $\begin{array}{l}\text { Yield plant }^{-1} \\
\text { Seeds plant } \\
100 \text {-seed weight } \\
\text { Seeds pod } \\
\text { Pods plant } \\
\text { Pod }^{-1}\end{array}$ & $0.871^{* *}$ & $\begin{array}{l}0.007 \text { '”' } \\
0.082 " '\end{array}$ & $\begin{array}{l}0.766^{* *} \\
0.825^{* *} \\
0.192^{\mathrm{ns}}\end{array}$ & $\begin{array}{l}0.821^{* *} \\
0.976^{* * * *} \\
0.007^{\prime \prime \prime} \\
0.685^{*}\end{array}$ & $\begin{array}{c}0.093^{\prime \prime \prime} \\
-0.133^{\prime \prime \prime} \\
-0.503^{\mathrm{ns}} \\
0.109^{\mathrm{ns}} \\
-0.206 "\end{array}$ \\
\hline
\end{tabular}

$*, * *, * * *$, ns represent $5 \%, 1 \%, 0.1 \%$ and not significant, respectively.

Table $\mathbf{2 b}$. Correlation coefficients among some yield contributing characters of mungbean under optimum soil moisture (control) conditions.

\begin{tabular}{|c|c|c|c|c|c|}
\hline & Seeds Plant-' & 100 -seed weight & Seeds pod-' & Pods plant-' & Pod length \\
\hline Yield plant-' & $0.796^{* *}$ & $0.772^{* *}$ & $0.739^{*}$ & $0.796^{* *}$ & $0.145^{\mathrm{ns}}$ \\
\hline Seeds plant-' & & $0.955^{* * *}$ & $0.876^{* * *}$ & $0.984^{* * * *}$ & $0.073 " ” '$ \\
\hline 100 -seed weigh & & & $0.914^{* * *}$ & $0.908^{* * *}$ & $0.179^{\text {ns }}$ \\
\hline Seeds pod ${ }^{-1}$ & & & & $0.784^{* *}$ & $-0.026 "$ \\
\hline Pods plant ${ }^{-1}$ & & & & & 0.074 "'” \\
\hline
\end{tabular}

Table 2c. Correlation coefficients among yield contributing characters of mungbean under drought conditions.

\begin{tabular}{|c|c|c|c|c|c|}
\hline & \multicolumn{3}{|c|}{ Seeds Plant ${ }^{-1} 100$-seed weight Seeds pod-' } & Pods plant-' & Pod length \\
\hline $\begin{array}{l}\text { Yield plant }^{-1} \\
\text { Seeds plant-' } \\
100 \text {-seed weight } \\
\text { Seeds pod }{ }^{-1} \\
\text { Pods plant }\end{array}$ & $0.944^{* * *}$ & $\begin{array}{l}0.213^{\prime \prime} " \\
0.241 "\end{array}$ & $\begin{array}{l}0.855^{* *} \\
0.906^{* * *} \\
0.186^{\prime \prime \prime}\end{array}$ & $\begin{array}{l}0.917^{* * *} \\
0.981^{* * *} \\
0.246^{\prime \prime} \\
0.813^{* *}\end{array}$ & $\begin{array}{r}0.127^{\prime \prime \prime} \\
0.039^{\text {ns }} \\
0.201^{\text {ns }} \\
-0.008^{\prime \prime \prime} \\
0.048^{\prime \prime}\end{array}$ \\
\hline
\end{tabular}

Correlations among the seed yield and yield components under waterlogged conditions (Table 2a) show that seed yield was dependent on seeds per plant, seeds per pod and pods per plant. Seeds per plant was significantly related to seeds per pod and pods per plant. Seeds per pod had a weak significant relationship with pods per plant. The relationship between the other seed yield components were not significantly related to each other.

Table $2 \mathrm{~b}$ elucidates the relationships between seed yield and yield components of mungbean in control treatment. The seed yield in control treatment related significantly to all the yield components except pod length.

Under drought stress condition, seed yield related significantly to the same yield components as those of control plants (Table 2c). Seeds per plant had strong relationship with seeds per pod and pods per plant. Seeds per pod also related 
significantly with pods per plant.

\section{DISCUSSION}

Dry matter production in mungbean was reduced by both drought and waterlogging conditions. In general, the growth was better under drought conditions than under waterlogging conditions. But none of these two conditions were comparable with optimum soil moisture conditions. At harvest, growth in the stressed plants was suppressed to half of the control plot plants. The effect of waterlogging was more severe on root growth than shoot growth among all the treatments. The roots became fibrous and concentrated just below the surface of the soil. With the onset of waterlogging, a decrease in soil oxygen content results in restriction in root metabolism. The first manifestation of this is a decline in root conductance, leading to loss of guttation (Trought and Drew, 1980). The response of leaf area production was similar to response of dry matter production (Fig. 1), which indicates that dry matter production in mungbean is governed by soil moisture status through production of leaf area. Similar views were reported by Kriedman (1986) and Hamiciet al. (1990).

Two factors are mainly involved in the growth responses of mungbean. One factor is the size of the photosynthetic organ expressed by leaf area, and the other one is the photosynthetic activity expressed by NAR. Hisao (1973) stated that the expansion of leaves was very sensitive to stress conditions. In this study, waterlogging was found to restrict more severly the development of foliage than drought. Higher NAR in control plots compared to the other two treatments may be attributed to the higher CGR in this treatment. But Musgrave and Vanhoy (1989) reported an increased NAR in mungbean grown under waterlogging conditions compared to the control plants.

The dry matter partitioning between roots, above ground vegetative organs and reproductive growth were modified by water stress. Under waterlogging conditions, the root activity is suspended due to submergence. This may result in the loss of sink activity in the roots due to hypoxic environment enforced by waterlogging, which may give rise to decreased translocation of assimilates out of the photosynthetic tissues. In this study also higher proportion of dry matter in the leaves and stem supports this hypothesis. The relative increase in root-shoot ratio of the crop under drought condition may reflect an increase in the proportion of assimilate allocated to the roots, or a change in the rate of death of roots relative to tops. Since photosynthesis is more inhibited than translocation during stress, dry matter produced before flowering may be transferred from the stem and roots to the grains during grain filling (Gallagher et al., 1976).

It has been found from this study that both drought and waterlogging cause damage to CGR, NAR, LAI and root growth of mungbean but waterlogging has more severe effect compared to drought conditions.

The adverse effect of water stress on the development of leaf size has already been discussed. Limited cell enlargement which is responsible for reduced LAI under both waterlogged and drought conditions makes the canopy inefficient in receiving the light energy. Assuming that the length of the petiole is proportionate to the dry weight (Trung et al., 1985), the relative increase in petiole dry weight at the lower strata level 
in the waterlogged plants probably made the canopy less efficient in the interception of light (Murata, 1981). Isoda et al. (1984) has reported that the canopy structure in potato plants seemed to depend on the petiole arrangement rather than on the leaf size of each node. In mungbean, waterlogging seems to influence more the petiole length than drought condition. Although petiole determines the shape of the canopy of the plant, the role of leaf area of the plant can not be ignored.

The light extinction coefficient study states that a lower value of $\mathrm{K}$ is advantageous for energy utilization. In this study, control plants had comparatively large leaf area which was distributed into whole of the canopy. This might have contributed to the higher efficiency of light utilization in control plants. Water stress has severe effect on the productivity of mungbean which is a manifestation of the total effect of stress on the crop. Varma and Rao (1975) reported a sharp decline in the pod number and seed yield under both reduced and excess soil moisture levels. Both drought and waterlogging have separate influence on the physiological processes which affect the productivity. Experiments on irrigation timing imply the importance of avoiding drought stress immediately before and during flowering if optimum yields are to be harvested (Agarwal et al., 1976; Chiang and Hubbel, 1978; Trung et al., 1985). In this experiment, the onset of drought stress treatment reduced the growth and seed yield. The reduction in yield was mainly because of the reductions in seed number per plant and pods per plant. Water stress hastened the flowering and the days to maturity compared to the control plants. Muchow (1985) also expressed a similar view in his experiment with different legumes including mungbean..

Mungbeans are unsuitable in the wet tropics where the annual rainfall is more than $1,000 \mathrm{~mm}$ (Jain and Mehra, 1980). Sixty seven percent reduction in seed yield of high moisture stressed plants indicated the severity of waterlogging on the yield. Trung et al. (1985) also reported that a drastic reduction in seed yield of mungbean resulted due to waterlogging at flowering stage. The reason for this reduction was attributed to the inhibitory effect on symbiotic nitrogen fixation. Varma and Rao (1975) stated that excess of soil moisture was more detrimental to nodule number, nodule activity and seed yield than a soil moisture deficit. In this of study also the reduction in seed yield of stressed plants may be due to the reductions of pods per plant, seeds per pod and 100 seed weight.

The correlation study shows that pods per plant under both the water stress conditions mostly affected seed yield components and were identified as the major yield determing component under water stress conditions. It appears from the results of this study that waterlogging gave more severe effect on the overall process of crop production.

\section{REFERENCES}

Agarwal, S. K., N. K. Behl and M. K. Moolani 1976 Response of summer mung to levels of phosphorus and irrigation under different dates of planting. Indian J. of Agronomy, 21: 290291

Armstrong, W. and T. J. Gaynard 1976 The critical oxygen pressures for respiration in intact plants. Physiol. Plant., 37: ZOO-206

Chiang, M. V. and J. N. Hubbel 1978 Effect of irrigation on the mungbean yield. In: Proceedings 
1st International Mungbean Symposium. Asian vegetable Research and Development Center, Sanhua, Taiwan.

Gallgher, J. N., P. V. Biscoe and B. Hunter 1976 Effects of drought on grain growth. Nature., 264: $541-542$

Goldswaorthy, P. R. 1970 The canopy structure of tall and short sorghum. J.agric.Sci., Camb., 75: $121-131$

Hamid, A., F. Kubota, W. Agata and M. Morokuma 1990 photosynthesis, transpiration, dry matter accumulation and yield performance of mungbean plant in response to water stress. $J$. Fac. Agr. Kyushu Univ., 35: 81-92

Hisao, T. C. 1973 plant responses to water stress. Ann. Rev. Plant Physiol., 24: 519-570

Isoda, A., K. Nakaseko and K. Gotoh 1984 Some characteristics of two andigena (S. tuberosum ssp. andigena) strains in terms of dry matter production and canopy structure. Japan Jour. Crop Sci., 53: 416-422

Jain, H. K. and K. L. Mehra 1980 Evolution, adaption, relationships, and uses of the species Vigna cultivated in India. In: R.J.Summerfield and A.H.Buntings (eds.) Advances in Legume Science. Royal Botanic Gardens, Kiew, England, pp. 459-468

Jones, H. G. and J. E. Corlett 1992 Current topics in droght physiology. J. agric. Sci., Camb., 119: 291-296

Kriedemann, P. E. 1986 Stomata1 and photosynthetic limitations to leaf growth. Aust. J. Plant Physiol., 13: 15-31

Legg, B. J., W. Day, D. W. Lawlor and K. J. Parkinson 1979 The effects of drought on barley growth: models and measurements showing the relative importance of leaf area and photosynthetic rate. J. agric. Sci., Camb., 92: 703-716

Monteith, J. L. 1977 Climate and efficiency of crop production in Britain. Physiological Transactions of the Royal Society of London, Series B., 281: 277-297

Muchow, R. C. 1985 Phenology, seed yield and water use of grain legumes grown under different soil regimes in a semi-arid tropical environment. Field Crops Res., 11: 81-97

Murata,Y. 1981 Dependence of potential productivity and efficiency for solar energy utilization of leaf photosynthesis capacity in crop species. Japan Jour. Crop Sci., 50: 223-232

Musgrave, M. E. and M. A. Vanhoy 1989 A growth analysis of waterlogging damage in mungbean (Phaseolus aureus). Can. J. Bot., 67: 2391-2395

Phogat, B. S., D. P. Singh and P. Singh 1984a Responses of cowpea (Vigna unguiculata (L.) Walp) and mungbean (Vigna radiata (L.) Wilczek) to irrigation. I. Effects on soil-plant water relations, evapotranspiration, yield and water use efficiency. Irrig. Sic., 5: 47-60

Phogat, B. S., D. P. Singh and P. Singh 1984b Responses of cowpea (Vigna unguiculata (L.) Walp) and mungbean (Vigna radiata (L.) Wilczek) to irrigation. II. Effects on carbon dioxide exchange, radiation characteristics and growth. Irrig. Sci., 5: 61-72

Schulze, E.-D. 1986 Carbon dioxide and water vapor exchange in response to drought in atmosphere and in the soil. Ann. Rev. Plant Physiol., 37: 247-274

Sinclair, T. R. and M. M. Ludlow 1985 Who taught plants thermodynamics? The unfulfilled potential of plant water potential. Aust. J. Plant Physiol., 12: 213-217

Trung, B. C., S. Yoshida and Y. Kobayashi 1985 Influence of soil moisture stress on the nitrogen nutrition and grain productivity of mungbean. Japan Jour. Crop Sci., 54: 72-78

Trought, M. C. T. and M. C. Drew 1980 The development of waterlogging damage in wheat seedlings (Triticum aestivum L.). I. Shoot and root growth in relation to changes in the concentrations of dissolved gases and solutes in the soil solution. Plant and Soil, 54: 77-94

Varma, A. K. and N. N. S. Rao 1975 Effect of different levels of soil moisture on growth, yield, and some physiological aspects of nodulation in greengarm. Indian J.Agric. Sci., 45: 11-16

Wiedenroth, E. and J. Poskuta 1979 Photosynthesis, photorespiration, respiration of shoots, and respiration of roots of wheat seedlings as influenced by oxygen concentration. $Z$. Pflanzenphysiol., 89: 217-225 